\title{
INTERAKSI SOSIAL MASYARAKAT DI KOMPLEK RUMAH SUSUN CIPTA MENANGGAL SURABAYA
}

\author{
Bernadetta Budi Lestari \\ Universitas PGRI Adi Buana Surabaya \\ bernadetabudilestari@gmail.com
}

\begin{abstract}
Abstrak
Keputusan Presiden No.22 Tahun 2006 dan program percepatan pembangunan rusun di kawasan metropolitan dimaksudkan untuk mendorong terbentuknya Tim Koordinasi Daerah agar percepatan pembangunan rusun dapat dilaksanakan. Lokasi sosialisasi:Meliputi Perkotaan metropolitan seperti: Jakarta, Surabaya, Makasar, Medan, Batam, dan Bandung.Peneliti, adalah penghuni Rumah Salah satu Blok dari komplek rumah Susun Tersebut. Maka inilah yang menjadi satu-satunya alasan mengambil judul Penelitian "Interaksi Sosial Masyarakat Complek Rumah Susun Cipta Menanggal, gayungan, Surabaya".
\end{abstract}

Kata Kunci: rumah susun, percepatan pembangunan

\section{PENDAHULUAN}

Pesatnya urbanisasi di kota-kota besar dan metropolitan telah menyebabkan permasalahan akan ketersediaan lahan bagi perumahan. Akibat langka dan semakin mahalnya tanah di perkotaan, pembangunan perumahan baru layak huni bagi masyarakat berpenghasilan rendah cenderung menjauh dari tempat kerja (urban sprawl). Keadaan ini menimbulkan ketidakteraturan penatan ruang dan kawasan, permasalahan mobilitas manusia dan barang, beban investasi, operasional dan pemeliharaan prasarana dan sarana umum, produktivitas kerja serta berdampak buruk terhadap kondisi sosial dan lingkungan.

Berdasarkan sensus Badan Pusat Statistik (BPS) tahun 2000, diperoleh jumlah penduduk. Indonesia mencapai 203.4 juta jiwa dengan proyeksi jumlah penduduk rata-rata $1,5 \%$ per tahun, maka pada tahun 2007 jumlah penduduk Indonesia mencapai 224.90 juta jiwa. Berdasarkan sensus tersebut diketahui bahwa kekurangan rumah atau backlog rumah secara nasional hingga tahun 2007 mencapai 7,6 juta rumah tangga yang belum memiliki rumah di seluruh Indonesia.

Dengan pertimbangan tersebut pemerintah telah mencanangkan Gerakan Nasional Pengembangan Sejuta Rumah (GNPSR) pada tahun 2003, bagi masyarakat berpenghasilan menengah - bawah di kawasan perkotaan dengan jumlah penduduk lebih dari 1,5 jiwa sebagai salahsatu solusi pemecahan permasalahan pennukiman perkotaan. Hal ini secara teknis tertuang dalam Kebijakan dan Reneana Strategis Pembangunan 
Rumah Susun eli Kawasan Perkotaan tahun 2007-2011.

Dari beberapa studi pasea huni tentang Rumah Susun sebelumnya, konflik sosial antar penghuni maupun terhadap lingkungan disekitamya banyak ditemukan. Hal ini disebabkan selama ini Rusun yang dibangun oleh pemerintah perkotaan tidak mempertimbangkan kondisi psikologi, sosiologi dan prilaku masyarakat Indonesia yang mempunyai karakteristik yang berbeda antar daerah satu dengan daerah yang lain (Liliany Sigit Aritin, 2007).

Hal tersebut berdampak pada banyaknya Rusun yang telah dibangun dengan biaya milyaran rupiah tidak dapat berfungsi sebagaimana mestinya. Bahkan ironisnya yang terjadi saat ini terjadi alih fungsi yang seharusnya rusun tidak boleh diperdagangan menjadi salah satu aset jula beli dan kos-kosan bagi pihak-pihak tertentu.

Masalah seperti di atas mulai dirasakan di Surabaya, yang merupakan salah satu target pembangunan rusun di kawasan perkotaan metropolitan (www.skycrapercity.com/rumahsusun), sehingga perlu dilakukan penelitian yang terintegrasi pada beberapa rumah susun yang ada di Surabaya dengan karakter penghuni yang berbeda untuk mendapatkan konsep perancangan rumah susun yang berjati diri melalui pendekatan Psikologis di lingkungan kota Surabaya.

Konsep Perancangan Rumah Susun Yang Berjati diri Melalui Pendekatan Psikologi Lingkungan Di Kota Surabaya ini bertitik tolak dari tujuan mencari konsep perancangan rusun yang sesuai dengan psikologi, sosiologi dan jati diri masyarakat Surabaya. Tanpa meninggalkan segi kenyamanan penghuni baik secara fisik maupun psikis, konsep ini akan dapat dijadikan acuan dalam mendisain rumah susun pada masing-masing lokasi yang tentunya akan mendukung program percepatan pembangunan rumah susun yang telah dicanangkan oleh pemerintah dalam upaya pemenuhan kebutuhan perumahan bagi masyarakat berpenghasilan menengah ke bawah.

Bagi masyarakat sendiri, Konsep Perancangan Rumah Susun . Yang Berjati diri Melalui Pendekatan Psikologi Lingkungan Di Kota Surabaya ini akan memberikan kesempatan bagi masyarakat untuk ikut berpartisipasi dalam merencanakan ruang hunian sesuai dengan kebutuhan.

\section{METODE PENELITIAN}

Rancangan penelitian ini untuk mendapatkan pola yang praktis dalam penggalian data interaksi sosial di komplek Rumah Susun Cipta 
Menanggal. Variabel-variabel yang diteliti dalam penelitian ini adalah (1) variable Pemahaman Jnteraksi Sosial melalui perkuliahan Study Masyaraakat Indonesia; (2) Faktor Penyebab Interaksi Sosial Masyarakat di Complek Rumah Susun Cipta Menanggal Surabaya; (3) Variabel macam-macam kegiatan Sosial yang ada di Complek Rumah Susun Cipta Menanggal.

Prosedur penelitian yang dilakukan oleh peneliti adalah sebagai berikut.

1. Penelitian dimulai dengan telaah teoretik, menguraikan tentang: Interaksi Sosial masyarakat.

2. Kisi-kisi yang dikembangkan adalah angket mengenai Kegiatan Interaksi sosial yang terjadi di Komplek Rumah Susun Cipta Menanggal Surabaya.

Menentukan subyek penelitian yang terdiri dari Masyarakat Rumah Susun Blok 1, 2, 3, 4, 5, 6, 63, 65, 67, 69, 12, 14, 16, 18.

Metode adalah alat untuk mengumpulkan data yang dilakukan secara sistematis (Arikunto, 2006:222), setiap metode mempunyai tujuan untuk memperoleh ukuran tentang variable, dalam penelitian ini alat pengumpulan data terdiri dari 2 (macam) yaitu angket dan Hasil karya seni perorangan dan kelompok. Dalam penelitian ini pengumpulan data melalui Observasi dan Angket.

\section{HASIL PENELITIAN}

\section{Kondisi Interaksi Sosial Masyarakat}

\section{Kontak Sosial}

a. Orang perorangan

b. Orang perorangan dengan kelompok

c. Kelompok dengan kelompok

2. Komunikasi

a. Melalui grup whatsapp

b. Pengumuman tertulis di papan

c. Pengumuman tertulis disebarkan dirumah-rumah

\section{Bentuk-bentuk \\ Interaksi}

(Process of association)

a. Kerja sama (Cooperation)

b. Gotong royong

c. Bergining (pelaksanaan perjanjian jasa antara dua organisasi atau lebih

d. Kooplasi (cootation) penerimaan unsur-unsur baru dari organisasi politik

e. Koalisi (coalition) kombinasi antar dua organisasi

f. Join Ventrue, kerjasama dalam pengusahaan proyek

4. Akomodasi (accomodation)

a. Keseimbangan (equilibrian) baik perorangan, kelompok yang berkaitan dengan norma sosial. Akomodasi dimaksudkan untuk mengurangi perbedaan bahan dan mengurangi pertentangan 
b. Mencegah meledaknya suatu pertentangan untuk sementara waktu

c. Untuk membina kerjasama antar kelompok

d. Mengusahakan peleburan kelompok-kelompok sosial yang terpisah.

\section{Bentuk-bentuk akomodasi}

a. Coerciom, akomodasi yang prosesnya dilaksanakan dengan paksaan, kelompok yang kuat memaksa yang lemah

b. Compromise, bentuk akomodasi dimana masing-masing pihak menurangi tuntutan agar tercapai kesepakatan

c. Arbitration, penyelesaian melalui pihak ketiga

d. Mediation, hampir sama dengan arbitration

e. Conciliation, mempertemukan keinginan bagi pihak yang bersangkutan untuk mengadakan asimilasi

f. Toleration (tolerant participation), kadang muncul secara spontan tanpa ada rencana

g. Stalemate, pihak yang berhubungan sudah pada titik klimaks, tidak lagi maju dan tidak lagi mundur

6. Hasil Akomodasi

a. Akomodasi dalam integrasi masyarakat telah berbuat banyak untuk menghindari pertentangan latent b. Menekan oposisi, seringkali suatu persaingan dilakukan demi keuntungan satu kelompok

c. Koordinasi berbagai kepribadian yang berbeda

\section{PEMBAHASAN}

Ada perbedaan wilayah administrasi antara unipa dan lokasi Penelitian yaitu, kelurahan Menanggal dan kalurahan Dukuh menanggal yang berjarak $1 \mathrm{~km}$. namun keduanya masih satu wilayah kecamatan gayungan. Adapun peneliti kebetulan berdomisili di komplek Rumah Susun Cipta Menanggal di blok 63 HH3. Dengan demikian layaklah bila peneliti memahami seluk beluk wilayahnya. Adapun akses antara unipa dan tempat penelitian sangat mudah di tempuh, sepuluh menit jalan kaki, ataupun 2 menit naik motor. Demikian yang menjadi alasan "Mengapa penelitian ini dilakukan?"

Dari segi geografis, kawasan padat pemukiman Rumah Susun Cipta Menanggal ini termasuk dalam wilayah strategis dan segitiga emas, yaitu dekat dengan jalan arteri atau jalan utama Achmad yani Surabaya dan kawasan religi masjid Al-Akbar Surabaya. Otomatis mendongkrak nilai jual dari harga persil unit rumah susun tersebut meski per unit berstatus SHGB. Jika harga tanah area menanggal sekitar Rp4.000.000/meter persegi (NJOP 2015) 
maka luas tanah dengan tipe rumah susun 36 adalah sekitar Rp144.000.000, sedangkan untuk NJOP tiap unit rumah susun ini sekitar Rp500.000.000, $50 \%$ lebih murah dari harga apartemen De Papilio yang telah terjual habis tahun 2016 dan trans Icon yang sedang dibangun tahun 2018 ini. Untuk status tanah area rumah susun masih milik PT. Perumnas selaku BUMN dan pemegang program-program perumahan rakyat.

Pada tahun 2016 pemkot Surabaya memiliki target pemukiman berupa 500 bangunan apartemen baik milik BUMN seperti PT. WIKA, Perumnas dan dinas PU maupun Swasta seperti Ciputra, Pakuwon dan Dharmawangsa grup sehingga diharapkan banyak warga Surabaya kelas menengah memiliki hunian dan terintegrasi dengan tempat kerja dan rekreasi.

Komplek Rumah Susun Cipta Menanggal terdiri dari 11 bangunan Rusun, 1 masjid, 1 Lapangan Tenis, dan 1 Balai RW. Dengan luas lahan 6 ha., jumlah penduduknya 856 jiwa., termasuk daerah Surabaya bagian selatan, hampir berdekatan dengan batas wilayah kabupaten Sidoardjo. Daerahnya cukup strategis. Akses ke kota Surabaya mudah, begitu juga ke kota lain. Dekat terminal bungur asih (5 $\mathrm{km})$. Ke Bandara juanda $17 \mathrm{~km}$, ke Stasiun Kereta Api Wonokromo yang berkisar $10 \mathrm{~km}$ jarak ke masjid Agung Nasional Al-Akbar Surabaya sekitar 500 m. Dengan demikian maka Rumah Susun Cipta Menanggal termasuk hunian yang cukup nyaman dan Murah. Fasilitas PDAM, Listrik, MCK cukup memadai. Warganya cukup sejahtera, dengan ditandai banyak yang memiliki mobil mewah diatas harga 300 juta.

Profil Rumah Susun Cipta Menanggal. Setiap Blok terdiri dari 64 KK (unit rumah). Setiap unit rumah dilengkapi dengan 2 kamar tidur, balcon, ruang tamu, dapur dan Kamar Mandi WC.Sarana Penerangan Listrik juga tidak pernah padam.Begitupun sarana PDAM juga jarang mati.

Dengan kata lain, jika mau hidup hemat biaya, tentu saja tinggal di Rumah Susun Cipta Menanggal. Namun demikian banyak juga yang bisa hidup berkecukupan hingga mewah, dengan ditandai: Sarana AC, Parabola dan lain-lain.

\section{Kondisi Sosial Ekonomi Masyarakat}

Beberapa penghuni rumah susun ada yang bekerja sebagai PNS dan ASN, buruh pabrik, mahasiswa, pekerja proyek, wirausaha, pedagang, wartawan, sopir taksi online dan ojek online, guru, dosen, serabutan, dan lain sebagainya.

Penghuni Rumah Susun Cipta Menanggal rata-rata dihuni oleh orang- 
orang perantauan dari berbagai propinsi di seluruh Indonesia, mulai dari Indonesia Bagian barat seperti Aceh, medan, Palembang, jawa barat, jawa tengah, jawa timur pada khususnya. Sedangkan perantau dari wilayah Indonesia bagian barat kebanyakan datang dari Sulawesi, warga pengungsian wilayah konflik ambon pada tahun 1998-2001, Kupang, Flores dan Kepulauan Arafura, hingga perantauan dari Papua.

Beberapa masyarakat Rumah Susun Cipta Menanggal juga banyak yang memiliki mobil, menandakan tingkat ekonomi mereka yang berada pada tingkat atas. Mobil dinas bagi ASN, dan mobil taksi online banyak juga yang terparkir di area lapangan voli. Lapangan Voli banyak yang dialih-fungsikan menjadi tempat parkir mobil dan dibangun kanopi-kanopi oleh warga sebagai pelindung mobil dari cuaca.panas dan hujan.Dengan kondisi multi-kultural dan multi-etnis maka toleransi di antara umat beraama sangat dijaga. Hal-hal sensitif dalam agama manapun hampir tidak pernah dijadikan bahan perseteruan oleh pihak-pihak tertentu yang tidak bertanggung jawab.

Saat masyarakat muslim merayakan hari besar perayaan kagamaan Idul Fitri, tradisi unjungunjung atau bersilaturahim antar tetangga tetap dilaksanakan dengan cara mengunjungi satu rumah ke rumah lainnya meski berbeda agama, mereka saling berkumpul dan larut dalam kebahagiaan perayaan keagamaan Idul Fitri. Begitu pun sebaliknya saat Perayaan keagamaan katolik maupun protestan di Hari Natal, masyarakat saling mengunjungi rumah-rumah mereka meskipun minoritas, namun suasana kidmad danbahagia terjalin dengan sangat baik.

Selain toleransi antar umat beragama, kerukunan antar warga rumah susun pun terjalin baik dengan adanya arisan ibu-ibu dasa wisma, arisan ibu-ibu PKK dan arisan bapakbapak, dimana semua informasi tentang pemerintahan pusat maupun kota disampaikan oleh ibu RT maupun bapak RT dalam acara tersebut. Informasi penting lainnya seperti kegiatan social dan kerja bakti tetap diberitahukan dan di musyawarahkan oleh masing-masing warga.Aspirasi warga seperti rehabilitasi bangunan, pengaturan parkir, dan air keruh PDAM pun dapat disampaikan dalam acara-acara tersebut.Secara tidak langsung kerukunan antar warga dapat terjalin dengan baik dengan adanya komunikasi dua arah antar warga Rumah Susun Cipta Menanggal.

Di era modern sekarang ini, pemanfaatan teknologi sangat menguntungkan terutama dalam bidang teknologi komunikasi. Salah 
satunya adalah media sosial di internet seperti Whatsapp atau telegram dan tak tanggung-tanggung warga Rumah Susun Cipta Menanggal memanfaatkannya sebagai komunikasi untuk menyampaikan informasi penting maupun bercanda dengan warga, sekaligus berbagi foto pada kegiatan-kegiatan tertentu seperti rekreasi warga maupun perayaan hari kemerdekaan Republik Indonesia.

Selain itu, tak hanya teknologi modern saja yang digunakan, pemberitahuan penting lainnya secara tradisional masih dapat dijumpai di mading dekat area anak tangga rumah susun sebagai pemberitahuan bagi masyarakat yang belum ataupun tidak memiliki gawai canggih seperti ponsel pintar dan ataupun keterbatasan dengan dunia internet khususnya bagi warga rumah susun yang lanjut usia. Media komunikasi yang tertempel seperti mading selain berisi tentang pemberitahuan pelaksanaan arisan dan posyandu atau poslansia, juga berisi tentang berbagai laporan keuangan kas RT dan iuran kampung menanggal. Terkadang juga berisi tentang posterposter penyuluhan dari puskesmas, hingga brosur orang berjualan obat.

\section{SIMPULAN}

Berdasarkan pemaparan data diatas maka dapat disimpulkan bahwa Interaksi sosial masyarakat di komplek
Rumah Susun Cipta Menanggal masih sangat bersifat positif, nyaman untuk di huni, dan dinamis dimana faktor imitasi, faktor Sugesti, faktor identifikasi, dan faktor simpati masih sangat kental terasa di system masyarakat sekitar. Ditambah dengan tenggang rasa, tingkat toleransi antar umat beragama yang tinggi, serta guyub rukun dalam membangun rasa kekeluargaan semakin kuat menunjukan identitas diri yang Dinamis.

\section{DAFTAR PUSTAKA}

Choirul Mahfud. 2006. Pendidikan Multikultural. Yogyakarta: Pustaka Pelajar.

Parsudi Suparlan. Tersedia pada http://www.interseksi.org/public ations/essays/articles Lmasyarakat majemuk.html.

Diakses tanggal 16 Februari 2009.

Soemardjan, Selo-Soemardi. 1974. Setangkai Bunga Sosiologi. Jakarta: Lembaga Penerbit Fakultas Ekonomi Universitas Indonesia. 